\title{
First outbreak of an infection with infectious spleen and kidney necrosis virus (ISKNV) in ornamental fish in Germany
}

\author{
Verena Jung-Schroers ${ }^{1, *}$, Mikolaj Adamek ${ }^{1}$, Peter Wohlsein ${ }^{2}$, Jan Wolter ${ }^{3}$, \\ Helmut Wedekind ${ }^{4}$, Dieter Steinhagen ${ }^{1}$ \\ ${ }^{1}$ Fish Disease Research Unit, University of Veterinary Medicine, 30559 Hannover, Germany \\ ${ }^{2}$ Department of Pathology, University of Veterinary Medicine, 30559 Hannover, Germany \\ ${ }^{3}$ Zierfischpraxis (Veterinary Practice for Ornamental Fishes, Tegeler Weg 24, 10589 Berlin, Germany \\ ${ }^{4}$ Institute for Fisheries, Bavarian State Research Center for Agriculture, 82319 Starnberg, Germany
}

\begin{abstract}
In 2014, infectious spleen and kidney necrosis virus (ISKNV), a member of the genus Megalocytivirus, was detected for the first time in ornamental fish in Germany. Since 2013, angelfish Pterophyllum spp. originating from Colombia have experienced significant epizootics in a number of German retailers' facilities. The diseased fish showed symptoms such as increased ventilation, swollen gills, and ulcerations of the skin. In 2014, diseased angelfish $P$. altum and platys Xiphophorus maculatus maintained in the same recirculating system were examined. Histopathological lesions included hypertrophic cells, single-cell necrosis, and an inflammatory infiltration of granulocytes, lymphocytes, and macrophages in liver, spleen, and kidney. Transmission electron microscopy revealed the presence of numerous polygonal viral particles (150 nm in diameter) within the cytoplasm of enlarged cells. A PCR assay for the detection of megalocytiviruses amplified $777 \mathrm{bp}$ of major capsid protein gene that was $100 \%$ identical to ISKNV. This is the first report of an ISKNV outbreak in Germany that most probably was introduced by infected angelfish from Colombia. To our knowledge, this is the first report of ISKNV detected in fish imported from South America. Given the lethal nature of megalocytiviruses, proper biosecurity would seem prudent in countries like Germany where these emerging pathogens are not established.
\end{abstract}

KEY WORDS: Infectious spleen and kidney necrosis virus - Megalocytivirus - Iridoviridae Angelfish $\cdot$ Pterophyllum sp. X Xiphophorus maculatus

\section{INTRODUCTION}

Iridoviruses cause severe diseases in many fish species, including ornamental, farmed, and wild fish. Megalocytivirus is the most recently established genus in the family Iridoviridae. It consists of a type species, Infectious spleen and kidney necrosis virus, that can be divided into 3 genotypes: Red sea bream iridovirus (RSIV), Turbot reddish body iridovirus

${ }^{*}$ Corresponding author:

verena.jung-schroers@tiho-hannover.de
(TRBIV), and Infectious spleen and kidney necrosis virus (ISKNV). A recent phylogenetic analysis of a megalocytivirus infecting a marine ornamental fish revealed that the ISKNV genotype can be further divided into 2 groups or clades, where the second clade is formed by the Threespine stickleback iridovirus (Sriwanayos et al. 2013).

ISKNV was first detected in 1994 in Chinese mandarin fish Siniperca chuatsi, resulting in severe

() The authors 2016. Open Access under Creative Commons by Attribution Licence. Use, distribution and reproduction are unrestricted. Authors and original publication must be credited. 
economic losses (He et al. 2002). Infected fish showed anorexia, petechial hemorrhages, abnormal swimming, and pale coloration (He et al. 2002). Gross changes included swelling of the kidneys and spleen. Histopathologically, hypertrophic cells with large basophilic cytoplasmic inclusions were found in spleen, kidney, gill tissue, cranial connective tissue, and the endocardium (He et al. 2002). Transmission electron microscopy (TEM) revealed viral particles with a diameter of approximately $150 \mathrm{~nm}$ in the affected tissues. For many years, ISKNV infections were restricted to several Asian countries, especially to China, Singapore, Taiwan, and Korea (Jeong et al. 2008, Tanaka et al. 2014). ISKNV infections were then reported in the USA (Yanong \& Waltzek 2013) and Japan (Tanaka et al. 2014). In Australia, an iridovirus was detected in farmed murray cod Maccullochella peelii peelii that has been identified as a strain of ISKNV (Lancaster et al. 2003, Go \& Whittington 2006). In addition, the presence of ISKNV was reported in 97 of 111 ornamental fish imported into Australia from Singapore, Malaysia, and Sri Lanka (Nolan et al. 2015) and in 10 of 14 species or varieties of ornamental fish that were imported to Australia (Rimmer et al. 2015). ISKNV infections occur in a great number of fishes, including freshwater, brackish, and marine species. More than 50 species of wild and cultured marine fish from the South China Sea are susceptible to ISKNV or ISKNV-like viruses (Wang et al. 2007). Additionally, many popular freshwater ornamental fish species, including cichlids such as the angelfish Pterophyllum scalare, livebearers, and a number of gourami species, are susceptible to ISKNV (Yanong \& Waltzek 2013). Some additional fish species including zebrafish Danio rerio can be experimentally infected (Xu et al. 2008). ISKNV infection can be symptomatic or asymptomatic. By analyzing 10 different freshwater ornamental species, Jeong et al. (2008) showed that all species were infected with ISKNV, but not all of them showed disease symptoms. Transmission of the virus seems to be possible via a horizontal route, through water from tanks with infected fish (He et al. 2002), and vertical transmission is also suggested (Jeong et al. 2008). Disease outbreaks occur at water temperatures above $20^{\circ} \mathrm{C}$ (He et al. 2002, Yanong \& Waltzek 2013). Here we report the first detection of ISKNV in clinically diseased ornamental fish in Germany.

In 2013, a number of German retailers suffered high losses of angelfish $P$. altum which had been imported from Colombia. The first clinical observed symptoms were anorexia and lethargy. By Day 3 to 5, diseased fish displayed increased ventilation and swollen gills. By Day 4 to 6, ulcerations of skin and fins and broken rays in the fins combined with secondary infections were seen. Mortalities were observed between Days 5 and 20 and ranged from 10 to $100 \%$. Parasites were not detected on skin or gills, and antibiotic treatments did not curb mortality. Transmission of the disease appeared to be possible from fish to fish, via water from the same recirculating system being shared between different tanks, and with virus-contaminated nets and pipes (Wedekind 2014). In 2014, fish from 1 of these retailers were analyzed systematically.

\section{MATERIALS AND METHODS}

\section{Fish}

In total, 5 groups of fish were examined (Table 1). Group 1 consisted of several hundred angelfish (imported from Colombia) that showed anorexia, lethargy, swollen gills, and skin ulcerations and died in 2013 and were kept at $-20^{\circ} \mathrm{C}$ until processed. Groups 2 to 5 consisted of diseased fish that presented with similar symptoms as observed in Group 1. Group 2 was a mixture of angelfish that were imported from Colombia and other sources that could not be identified, while Groups 3 to 5 consisted of platys Xiphophorus maculatus of unknown origin. The platys and angelfish were kept in separate tanks but within the same recirculating system.

Table 1. Groups of fish that were examined; nd: not determined

\begin{tabular}{|llcccc|}
\hline Group & Species & No. of fish & $\begin{array}{c}\text { Condition } \\
\text { on arrival }\end{array}$ & $\begin{array}{c}\text { Average } \\
\text { weight (g) }\end{array}$ & $\begin{array}{c}\text { Average } \\
\text { length (cm) }\end{array}$ \\
\hline 1 & Angelfish Pterophyllum altum & $\sim 500$ & Dead, frozen & nd & nd \\
2 & Angelfish Pterophyllum altum & 10 & Alive & 1.4 & 3.0 \\
3 & Platy Xiphophorus maculatus & 21 & Alive & 1.0 & 2.5 \\
4 & Platy Xiphophorus maculatus & 32 & Alive & 0.8 & 0.3 \\
5 & Platy Xiphophorus maculatus & 22 & Alive & 1.6 \\
\hline
\end{tabular}




\section{Examinations}

All fish from Groups 2 to 5 were clinically examined. Biopsies of the skin, gills, and intestine were examined for the presence of parasites by light microscopy. Fish from Groups 2 to 5 were euthanized by adding tricaine methanesulfonate (Pharmaq) to the water $(0.5 \mathrm{~g}$ added to $1 \mathrm{l}$ of water). Fish were dissected, and small pieces of liver, spleen, and kidney were directly examined by light microscopy for obvious organ lesions. In addition, the aforementioned organs were cultured for bacteria on blood agar plates as well as on tryptone soya agar plates at $25^{\circ} \mathrm{C}$ for $48 \mathrm{~h}$. After 24 and 48 h, bacterial growth was documented. Cultured bacteria were identified by using Gram staining and biochemical test kits (API Strips, Biomerieux) and additional tests depending on the results of the previous testing. Three to 10 whole fish from Groups 2 to 5 were fixed in $4 \%$ buffered formalin for histological examination. The formalin-fixed tissue was processed routinely, embedded in paraffin wax, cut at $4 \mu \mathrm{m}$, and stained with hematoxylin and eosin (HE) (Romeis 1968). TEM was performed on formalin-fixed tissue that was post-fixed in glutaraldehyde, dehydrated in graded ethanol series, and routinely embedded in epoxy resin. Ultrathin sections were stained with lead citrate and uranyl acetate and examined in a TEM (Zeiss EM10). Additional samples were taken from the visceral organs for DNA extraction. PCR assays targeting large DNA viruses (Waltzek et al. 2005), iridoviruses in general (Mao et al. 1997), ranaviruses in general (Hyatt et al. 2000), guppy virus 6 and doctor fish virus (Ohlemeyer 2009), and megalocytiviruses (Kurita \& Nakajima 2012) were performed to confirm the identity.
The details of the primers used for these reactions are given in Table 2. For each group, 6 fish were collected, and DNA was isolated from tissue pools containing gills, liver, spleen, and kidney using commercially available extraction kits (QIAamp DNA Mini Kit, Qiagen). PCR amplification was performed using the KAPA2G Robust Hot Start PCR kit (Peqlab).

\section{RESULTS}

None of the examined fish had skin lesions or parasites; however, we found acid-fast bacteria in 1 group of platys. Thus, bacteria were not considered a significant cause of disease in these cases. In fresh squash preparations of liver, spleen, and kidney of angelfish from Group 2 and platys from Group 4, high numbers of melanomacrophages were detected. In addition, angelfish from Group 2 had granulomas and petechial hemorrhages in the spleen and liver, respectively. Histopathological examination revealed the presence of hypertrophic basophilic stained cells in the kidneys, spleen, and liver of the fish from all groups (Figs. 1 \& 2a). In general, alterations were primarily seen in fibroblastic cells. In the kidney, most of the altered cells were located in the interstitium adjacent to the renal tubules (Fig. 1). In the liver, only scattered hypertrophic cells were observed (Fig. 2). In addition, single-cell necrosis (Fig. 2b) and infiltration of granulocytes, lymphocytes, and macrophages were noted in the liver, spleen, and kidney. TEM revealed numerous viral particles with a capsid of $150 \mathrm{~nm}$ in diameter in the cytoplasm of the enlarged cells (Fig. 3).

Table 2. Primers used for PCR analysis

\begin{tabular}{|c|c|c|c|c|c|}
\hline $\begin{array}{l}\text { Viruses } \\
\text { identified }\end{array}$ & Direction & Name & $\begin{array}{l}\text { Primer } \\
\text { Sequence }\left(5^{\prime}-3^{\prime}\right)\end{array}$ & $\begin{array}{l}\text { Amplicon } \\
\text { size (bp) }\end{array}$ & Source \\
\hline $\begin{array}{l}\text { Allo- } \\
\text { herpesviruses }\end{array}$ & $\begin{array}{l}\text { Forward: } \\
\text { Reverse: }\end{array}$ & $\begin{array}{l}\text { UnHV_DNAP_F } \\
\text { UnHV_DNAP_R }\end{array}$ & $\begin{array}{l}\text { CGGAATTCTAGAYTTYGCNWSNYTNTAYCC } \\
\text { CCCGAATTCAGATCTCNGTRTCNCCRTA }\end{array}$ & $\sim 500$ & $\begin{array}{l}\text { Waltzek et } \\
\text { al. (2005) }\end{array}$ \\
\hline Iridoviruses & $\begin{array}{l}\text { Forward: } \\
\text { Reverse: }\end{array}$ & $\begin{array}{l}\text { MCP } 4 \\
\text { MCP } 5\end{array}$ & $\begin{array}{l}\text { GACTTGGCCACTTATGAC } \\
\text { GTCTCTGGAGAAGAAGAA }\end{array}$ & $\sim 500$ & $\begin{array}{l}\text { Mao et al. } \\
\quad(1997)\end{array}$ \\
\hline Ranaviruses & $\begin{array}{l}\text { Forward: } \\
\text { Reverse: }\end{array}$ & $\begin{array}{l}\text { MCP-1 } \\
\text { MCP-2R }\end{array}$ & $\begin{array}{l}\text { CAGCGTGTATCTTATAATAAAAAGAAATG } \\
\text { GGCTCCGTCCTGGCCTGTG }\end{array}$ & 543 & $\begin{array}{l}\text { Hyatt et al. } \\
\text { (2000) }\end{array}$ \\
\hline $\begin{array}{l}\text { Guppy virus } \\
6 \text {, doctor fish } \\
\text { virus }\end{array}$ & $\begin{array}{l}\text { Forward: } \\
\text { Reverse: }\end{array}$ & $\begin{array}{l}\text { DF-1 } \\
\text { DF-2 }\end{array}$ & $\begin{array}{l}\text { GATCTCGCCACTTATGACAGC } \\
\text { GTGTAGTTGGAACCCACAGAC }\end{array}$ & 923 & $\begin{array}{l}\text { Ohlemeyer } \\
\text { (2009) }\end{array}$ \\
\hline $\begin{array}{l}\text { Megalocyti- } \\
\text { viruses }\end{array}$ & $\begin{array}{l}\text { Forward: } \\
\text { Reverse: }\end{array}$ & $\begin{array}{l}\text { MCP-uni332-F3 } \\
\text { MCP-uni1108-R8 }\end{array}$ & $\begin{array}{l}\text { AGGTGTCGGTGTCATTAACGACCTG } \\
\text { TCTCAGGCATGCTGGGCGCAAAG }\end{array}$ & 777 & $\begin{array}{c}\text { Kurita \& } \\
\text { Nakajima (2012) }\end{array}$ \\
\hline
\end{tabular}




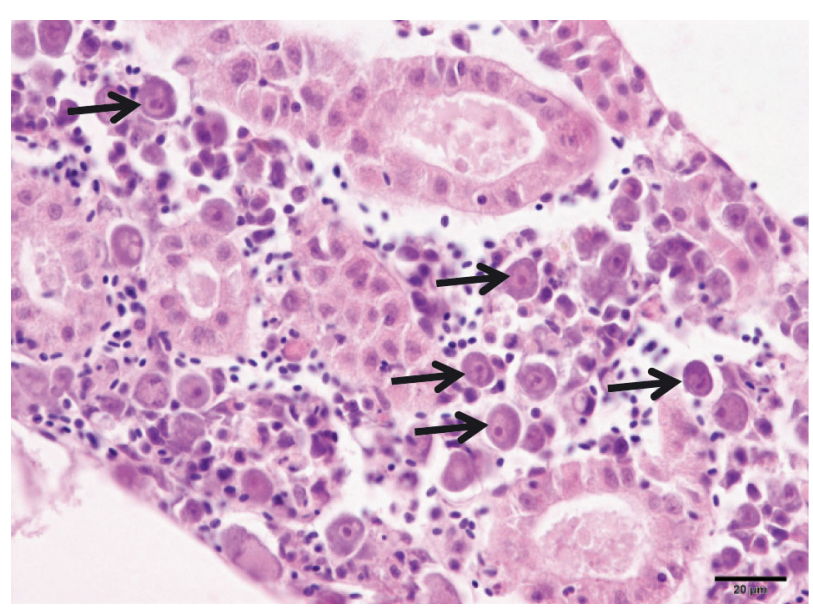

Fig. 1. Histopathology of kidney tissue from an infectious spleen and kidney necrosis virus-infected platy Xiphophorus maculatus showing multiple basophilic hypertrophic stained cells (arrows). H\&E stain. Scale bar $=20 \mu \mathrm{m}$



Fig. 2. Histopathology of liver tissue from infectious spleen and kidney necrosis virus-infected platys Xiphophorus maculatus showing (a) multiple basophilic hypertrophic cells (arrow) and (b) single-cell necrosis (arrow). H\&E stain. Scale bars $=20 \mu \mathrm{m}$

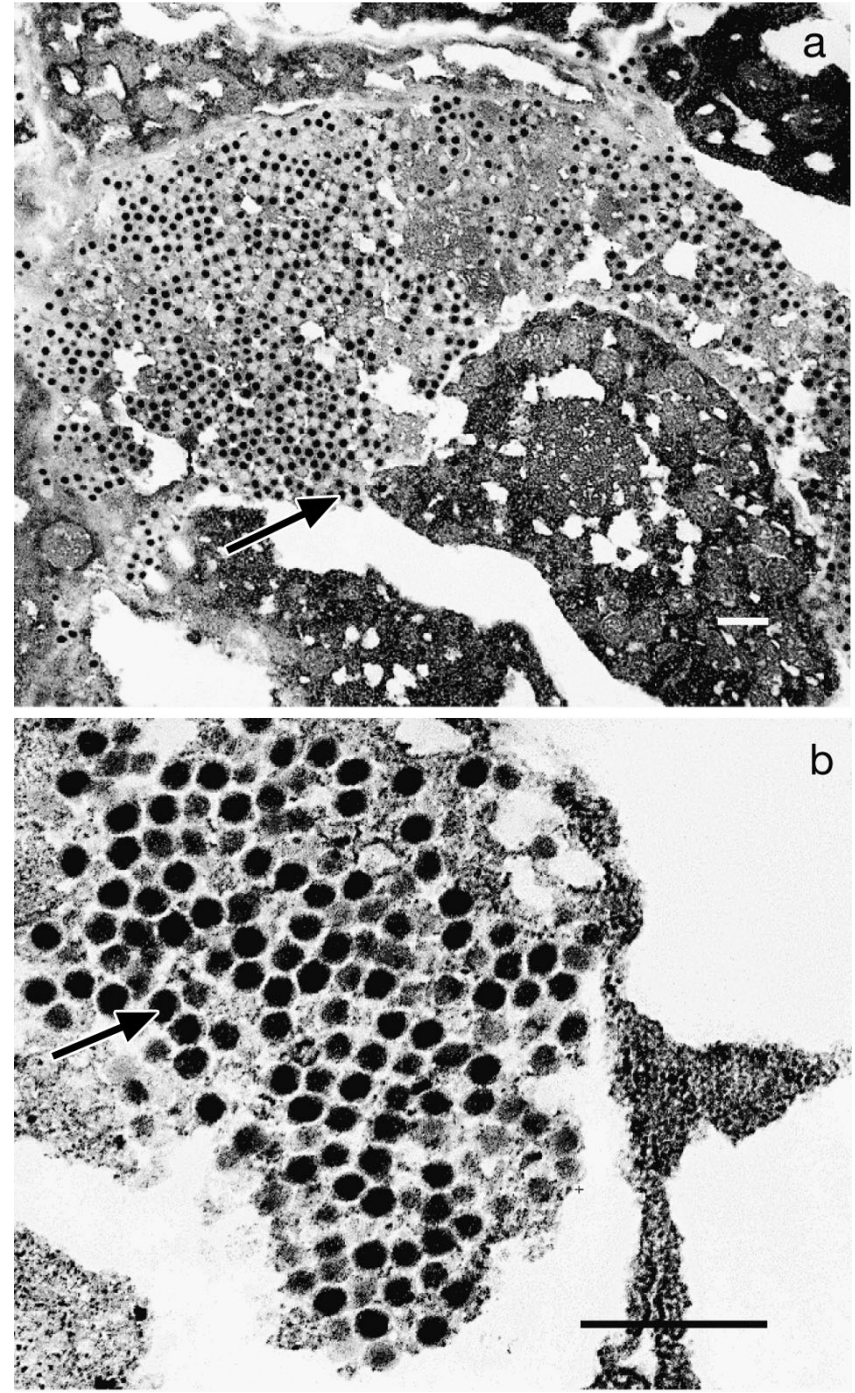

Fig. 3. Transmission electron photomicrographs of a platy Xiphophorus maculatus kidney cell containing large numbers of cytoplasmic polygonal infectious spleen and kidney necrosis virus virions. Scale bars $=500 \mathrm{~nm}$

PCRs for iridoviruses in general, ranaviruses in general, guppy virus 6, and doctor fish virus were negative. The PCR designed to amplify the DNA polymerase of large DNA viruses produced a product of $500 \mathrm{bp}$ which was sequenced and found to be $99 \%$ identical to the ISKNV DNA polymerase gene of sequences from the GenBank database (AF371960.1, FN429981.1). The PCR for detection of megalocytiviruses resulted in the amplification of a $777 \mathrm{bp}$ major capsid protein (MCP) gene which was 100\% identical to 9 ISKNV nucleotide sequences (KF 753323.1, HQ317460.1, AF371960.1, AF370008.1, KP292960.1，KP292959.1，KP292958.1，KP292957.1， KP292956.1). 


\section{DISCUSSION}

One characteristic of Megalocytivirus infection is basophilic hypertrophic cells in almost all visceral organs. The pathology seen in the examined fish, especially the appearance of hypertrophic basophilic cells and single-cell necrosis in the interstitium is indicative of megalocytivirus infection (Rodger et al. 1997, Paperna et al. 2001, Gibson-Kueh et al. 2003). Sequencing the PCR products confirmed an outbreak of ISKNV, and we concluded that the fish died following dysfunction of the internal organs.

Previous studies indicated that iridoviral infections lead to cell alterations in connective tissues and recommended fibroblastic cell lines for iridovirus isolation (Gibson-Kueh et al. 2003). Especially hepatic fibroblasts, hepatic perisinoisoidal cells, and renal interstitial cells might be the target cells of ISKNV in liver and kidney (Tanaka et al. 2014). This assumption is further strengthened by our histopathological findings, where the alterations were seen in fibroblastic cells of the infected fish.

This is the first report of the detection of ISKNV in ornamental fish in Germany. The angelfish were imported to Germany from Colombia. Until now there have been no reported cases of ISKNV infections in South America. The sequences of ISKNV in the database are from virus isolates from South East Asia, Australia, and the USA. The sequence of the MCP seems to be highly conserved, and the sequence detected from fish in Germany was identical to sequences from Asian and Australian isolates. It remains unclear whether the ISKNV from the infected angelfish originated from South America. Given the intensive intercontinental trade of ornamental fish species, it is also possible that the ISKVN arrived in Germany via Colombia from South East Asia. The susceptibility and transmission of iridoviruses from imported fish to endemic fish populations in Germany has not been investigated, but the examined platys that were kept in the same recirculating system could have been infected through the water. Nevertheless, platys are hosts for ISKNV (Nolan et al. 2015), and it could not be clarified whether they had already been infected when put together with the angelfish. Indeed, transmission of ISKNV from imported fish from Asia or South America to other fish in Germany is likely. The distribution of this virus in German fish populations and probably in fish populations in all of Europe is unknown, and further research, in particular epidemiological studies, is needed. Because of the severe progressive form of this infection and the potentially high mortal- ities, authorities should consider quarantining ornamental fish separately and examining them directly after import, especially if they originated from Asia or South America.

Acknowledgements. We thank Tobias Handt for excellent technical support.

\section{LITERATURE CITED}

Gibson-Kueh S, Netto P, Ngoh-Lim GH, Chang SF and others (2003) The pathology of systemic iridoviral disease in fish. J Comp Pathol 129:111-119

Go J, Whittington R (2006) Experimental transmission and virulence of a megalocytivirus (Family Iridoviridae) of dwarf gourami (Colisa lalia) from Asia in Murray cod (Maccullochella peelii peelii). Aust Aquacult 258: 140-149

He JG, Zeng K, Weng SP, Chan SM (2002) Experimental transmission, pathogenicity and physical-chemical properties of infectious spleen and kidney necrosis virus (ISKNV). Aquaculture 204:11-24

$>$ Hyatt AD, Gould AR, Zupanovic Z, Cunningham AA and others (2000) Comparative studies of piscine and amphibian iridoviruses. Arch Virol 145:301-331

Jeong JB, Kim HY, Jun LJ, Lyu JH, Park NG, Kim JK, Jeong HD (2008) Outbreaks and risks of infectious spleen and kidney necrosis virus disease in freshwater ornamental fishes. Dis Aquat Org 78:209-215

Kurita J, Nakajima K (2012) Megalocytiviruses. Viruses 4: 521-538

Lancaster MJ, Williamson MM, Schroen CJ (2003) Iridovirus-associated mortality in farmed Murray cod (Maccullochella peelii peelii). Aust Vet J 81:633-634

Mao J, Hedrick RP, Chinchar VG (1997) Molecular characterization, sequence analysis, and taxonomic position of newly isolated fish iridoviruses. Virology 229: 212-220

Nolan D, Stephens F, Crockford M, Jones JB, Snow M (2015) Detection and characterization of viruses of the genus Megalocytivirus in ornamental fish imported into an Australian border quarantine premises: an emerging risk to national biosecurity. J Fish Dis 38:187-195

Ohlemeyer S (2009) Identifizierung und Differenzierung ausgewählter Iridoviren. PhD dissertation, Ludwig-Maximilians-University Munich

Paperna I, Vilenkin M, de Matos APA (2001) Iridovirus infections in farm-reared tropical ornamental fish. Dis Aquat Org 48:17-25

Rimmer AE, Becker JA, Tweedie A, Lintermans M, Landos M, Stephens F, Whittington RJ (2015) Detection of dwarf gourami iridovirus (Infectious spleen and kidney necrosis virus) in populations of ornamental fish prior to and after importation into Australia, with the first evidence of infection in domestically farmed platy (Xiphophorus maculatus). Prev Vet Med 122:181-194

Rodger HD, Kobs M, Macartney A, Frerichs GN (1997) Systemic iridovirus infection in freshwater angelfish, Pterophyllum scalare (Lichtenstein). J Fish Dis 20:69-72

Romeis B (1968) Mikroskopische Technik, Vol R. Oldenbourg Verlag, München-Wien

Sriwanayos P, Francis-Floyd R, Stidworthy MF, Petty BD, Kelley K, Waltzek TB (2013) Megalocytivirus infection in 
orbiculate batfish Platax orbicularis. Dis Aquat Org 105: $1-8$

Tanaka N, Izawa T, Kuwamura M, Higashiguchi N and others (2014) The first case of infectious spleen and kidney necrosis virus (ISKNV) infection in aquarium-maintained mandarin fish, Siniperca chuatsi (Basilewsky), in Japan. J Fish Dis 37:401-405

Waltzek TB, Kelley GO, Stone DM, Way K and others (2005) Koi herpesvirus represents a third cyprinid herpesvirus (CyHV-3) in the family Herpesviridae. J Gen Virol 86: 1659-1667

Wang YQ, Lu L, Weng SP, Huang JN, Chan SM, He JG (2007) Molecular epidemiology and phylogenetic analy-

Editorial responsibility: Mark Crane,

Geelong, Victoria, Australia sis of a marine fish infectious spleen and kidney necrosis virus-like (ISKNV-like) virus. Arch Virol 152:763-773

Wedekind H (2014) Infektionen bei Pterophyllum sp. Meeting of the workgroup 'Ornamental fish' of the German branch of the European Association of Fish Pathologists, Starnberg, Germany

> Xu X, Zhang L, Weng S, Huang Z and others (2008) A zebrafish (Danio rerio) model of infectious spleen and kidney necrosis virus (ISKNV) infection. Virology 376: $1-12$

Yanong RPE, Waltzek TB (2013) Megalocytivirus infections in fish, with emphasis on ornamental species. UF/IFAS Extension FA182. University of Florida, Gainesville, FL

Submitted: September 16, 2015; Accepted: March 23, 2016 Proofs received from author(s): May 4, 2016 